\title{
Marek Wiśniewski, Dystrybucyjne właściwości odprzymiotnikowych nazw cech we wspótczesnej polszczyźnie, Toruń 2005
}

Książka Marka Wiśniewskiego Dystrybucyjne właściwości odprzymiotnikowych nazw cech we wspótczesnej polszczyźnie zawiera propozycję formalnego opisu cech składniowych (dokładniej dystrybucyjnych) tytułowych jednostek (dalej w skrócie: $N E(A d j))$ i porównanie tych cech z właściwościami składniowymi motywujących je leksemów przymiotnikowych. Podjęta przez autora problematyka jest ciekawym przedsięwzięciem badawczym i to z kilku powodów. Po pierwsze, składnia przymiotników jest znacznie bogatsza, niżby się na pozór wydawało, można zatem oczekiwać ciekawych własności motywowanych przez nie rzeczowników. Po drugie, analiza dystrybucyjna omawianych jednostek nie miała dotąd monograficznego opracowania. Ponadto problematyka ta jest istotna również $\mathrm{z}$ socjolingwistycznego punktu widzenia, bowiem $\mathrm{w}$ ostatnich latach widać wyraźną zmianę uzusu w tworzeniu $N E(A d j)$, polegającą na wyraźnym rozszerzeniu zakresu tworzenia jednostek należących do tej kategorii słowotwórczej.

Metody opisu językowego autor opiera na rozwiązaniach proponowanych w formalnych kierunkach polskiej składni, zwłaszcza przedstawionych przez Zygmunta Saloniego i Marka Świdzińskiego w Składni wspótczesnego języka polskiego (dalej: SWJP). Nie dziwi zatem, że autor bada kompetencję językową, nie zaś jej tekstową realizację, a praca jego nie ma charakteru materiałowego.

Celem podjętej przez Marka Wiśniewskiego pracy jest przede wszystkim dystrybucyjna charakterystyka $N E$ (Adj). Ponadto autor pokazuje, na ile dziedziczą one wymagania po swych bazach słowotwórczych oraz buduje kryteria dystrybucyjnych klasyfikacji $N E(A d j)$ i motywujących je przymiotników. Wszystkie trzy cele bez wątpienia osiąga.

Wymienionym wyżej celom podporządkowano układ pracy, której zasadnicza część podzielona została na trzy rozdziały:

1. Granice klasy NE(Adj),

2. Teoretyczne podstawy składniowej charakterystyki NE (Adj),

3. Przeglad grup i klas NE(Adj). 
W pierwszym rozdziale autor dokładnie analizuje słowotwórcze mechanizmy tworzenia odprzymiotnikowych nazw cech, przy czym nie przyjmuje jako danych wniosków sformułowanych $\mathrm{w}$ dotychczasowej literaturze przedmiotu. Proponuje własny sposób interpretacji słowotwórczej struktury $N E(A d j)$, co wydaje się cenne ze względu na brak zgodności w kwestii dotychczasowych analiz budowy słowotwórczej wielu omawianych jednostek. W szczególności M. Wiśniewski odrzuca tezę o hierarchiczności środków słowotwórczych, przyjmując, iż wszystkie one pełnią funkcję formantu. Za równie ważne ze słowotwórczego punktu widzenia uznaje zarówno afiksy, jak i ewentualne redukcje tematów czy występujące w nich alternacje. Rozwiązanie to pozwala autorowi omawianej pracy uniknąć subiektywizmu i niekonsekwencji w interpretacji budowy słowotwórczej charakteryzowanych przez niego derywatów. Biorąc pod uwagę trzy wspomniane wyżej kryteria, autor wyróżnia, stosując metodę podziału dychotomicznego, wszystkie mechanizmy derywacyjne, leżące u podstaw tworzenia $N E$ (Adj). Najpierw dzieli zbiór analizowanych derywatów na dwie grupy: takie $N E(\operatorname{Adj})$, w których temat bazowego przymiotnika nie uległ redukcji, i na takie, w których temat został zredukowany. Każdą z tak wyodrębnionych grup dzieli następnie na dwie podgrupy na podstawie tego, czy w temacie zachodzą alternacje, czy też nie. Otrzymane w ten sposób cztery podgrupy rozpadają się z kolei na osiem (podział ciągle jest parami rozłączny) ze względu na to, czy został dodany do nich sam morfem gramatyczny, czy również afiks. W konsekwencji otrzymujemy 8 klas derywacyjnych:

1) derywaty paradygmatyczne, np. ciepło,

2) derywaty afiksalne, np. głuchota,

3) derywaty alternacyjno-paradygmatyczne, np. biel,

4) derywaty alternacyjno-afiksalne, np. pokrewieństwo,

5) derywaty redukcyjno-paradygmatyczne, np. spryt,

6) derywaty redukcyjno-afiksalne, np. niechlujstwo,

7) derywaty redukcyjno-alternacyjno-paradygmatyczne, np. potęga,

8) derywaty redukcyjno-alternacyjno-afiksalne, np. gorycz.

Przedstawiony wyżej opis technik derywacyjnych, które leżą u podstaw tworzenia $N E(A d j)$, jest klarowny, przemyślany metodologicznie i konsekwentny. Na szczególne podkreślenie zasługuje, w moim przekonaniu, udana próba zobiektywizowania kryteriów analizy słowotwórczej. Warto byłoby tę propozycję zastosować również do innych formacji.

Niewątpliwe rację ma $\mathrm{M}$. Wiśniewski, twierdząc, że same kryteria słowotwórcze są niewystarczające do wyróżnienia $N E($ Adj). Zwraca uwagę, że nie wszystkie derywaty odprzymiotnikowe, nawet tworzone od tych samych przymiotników czy za pomocą tych samych mechanizmów słowotwórczych, czasami wręcz synkretyczne, można zaliczyć do tego typu formacji. Podaje tu szereg przy- 
kładów, np. białość to 'bycie białym' (a zatem $N E($ Adj)), ale przyszłość to nie jest 'bycie przyszłym', bezczelność w zależności od kontekstu może być: 'byciem bezczelnym' (NE(Adj)) albo 'czymś, co jest bezczelne'. Konieczne do wyróżnienia omawianych jednostek staje się wprowadzenie nowych kryteriów - kryteriów składniowych. Do klasy $N E(A d j)$ M. Wiśniewski zalicza w rezultacie tylko te derywaty odprzymiotnikowe, które po przekształceniu we frazę zdaniową stają się tzw. orzecznikami, a występujące ewentualnie w zdaniu podrzędne wobec nich frazy przymiotnikowe natomiast - tzw. podmiotami: por.:

Przeraziła się bezczelnościa ojca (ew. ojcowa). = Przeraziła się tym, że ojciec jest bezczelny.

Taką ekwiwalencję uznaje za możliwą tylko wówczas, gdy spełnione są dwa warunki:

„a) derywat odprzymiotnikowy występuje w pozycji przy czasowniku konstytuującym analizowaną konstrukcję syntaktyczną i jest przezeń akomodowany pod względem kategorii przypadka,

b) derywat odprzymiotnikowy współwystępuje $\mathrm{z}$ podrzędnikiem dystrybucyjnym $(A P)$ wskazującym obiekt $\mathrm{z}$ rzeczywistości, dla którego charakterystyczna jest cecha nazywana przez nadrzędną $N E($ Adj).” (s. 29)

I ta obecność podrzędnej frazy przymiotnikowej jest - zdaniem autora najwyraźniejszym wyróżnikiem omawianej grupy derywatów.

Do powyższych stwierdzeń można mieć dwie uwagi. Pierwsza, drobna, to taka, że rzeczowniki zajmujące pozycje przyczasownikowe są z reguły (poza bardzo nielicznymi wypadkami specjalnych form wybranych rzeczowników występujących w funkcji przysłówkowej, np. spaceruje godzinami, co nie dotyczy omawianych tu kontekstów) przez nie akomodowane (i zawsze tylko pod względem przypadka). Uwaga druga zdaje się nieco poważniejsza. Otóż nie jest powiedziane wprost, że test opisany w punkcie b służy tylko do rozróżniania odprzymiotnikowych nazw cech od homonimicznych z nimi innych nazw, tzn. przy jego pomocy odróżnimy np. GŁUPOTĘ (NE) od GŁUPOTY (NATTR), por.:

Nie znoszę bezczelności $=$ Nie znoszę tego, że ktoś jest bezczelny $\approx$ 'bycia bezczelnym lub = Nie znoszę tego, co jest bezczelne $\approx$ 'bezczelnego zachowania, natomiast:

Nie znoszę jego bezczelności. to tylko Nie znoszę tego, że on jest bezczelny $\approx$ "bycia bezczelnym.

$\mathrm{Na}$ jego podstawie nie odróżnimy wszystkich odprzymiotnikowych nazw cech od innych typów derywatów odprzymiotnikowych, por. np. Nie znoszę jego twórczości (a TWÓRCZOŚĆ to na pewno nie $N E($ Adj $)$ ). A takie można odnieść wrażenie po lekturze omawianego fragmentu.

W rozdziale II: Teoretyczne podstawy składniowej charakterystyki NE (Adj) autor przedstawia typy kontekstów, w których występują zarówno symetryczne, jak i niesymetryczne $N E(A d j)$ po to, by następnie ograniczyć zakres scharaktery- 
zowanych przez siebie konstrukcji do tych, które powstały w wyniku prostych transpozycyjnych przekształceń zdań z bazowymi przymiotnikami. W konstrukcjach tych - jak wyjaśnia autor - mogą się pojawiać oba typy $N E(A d j)$, a zatem ich obserwacja gwarantuje jednakowe potraktowanie wszystkich jednostek. Uwaga wydaje się słuszna, bowiem konsekwencja jest niezwykle istotna w tego typu badaniach, zastanawiać się tylko można, czy zawężenie pola obserwacji nie powoduje utraty jakichś danych.

Ten rozdział, a szczególnie charakterystyka metody dystrybucyjnej charakterystyki $N E(A d j)$, wydaje się najlepszy w całej pracy. Za podstawowe narzędzie analizy strukturalnej autor uznaje badanie związków konotacyjnych i akomodacyjnych. Opiera się na ujęciu zaproponowanym przez Saloniego i Swidzińskiego (por. wyżej), jednak dokonuje modyfikacji ich aparatu pojęciowego oraz narzędzi opisu. Jego uwagi - choć nie ze wszystkimi się zgadzam - są bardzo interesujące. Przede wszystkim M. Wiśniewski zwraca uwagę, że uszczegółowienia wymaga repertuar fraz, a dokładniej fraz niewymaganych. Stanowią one bowiem w SWJP, bez względu na zajmowaną pozycję, a nawet pełnioną funkcję, jeden typ frazy. Takie ujęcie pozostaje w sprzeczności z zawartą w SWJP definicją frazy, która wyraźnie mówi, iż „typ frazy, jaki reprezentuje dana jednostka składniowa, określany jest przez jej miejsce wewnątrz innej jednostki składniowej (...) ze względu na funkcję, jaką pełni ona w obrębie konstrukcji wyższego rzędu" (za: Wiśniewski, s. 67), a ponadto znacznie utrudnia analizę niekonotowanych jednostek składniowych. Ponieważ większość podrzędników $N E(A d j)$ jest właśnie niekonotowana, M. Wiśniewski, decydując się na ujęcie w swoim opisie również redukowalnych członów składniowych, jest zmuszony do dokonania poważnych zmian w metodzie będącej podstawą jego opisu. $Z$ zadania tego wywiązuje się bardzo dobrze. Przede wszystkim wprowadza do swojej metody oprócz terminów „fraza” i „grupa” termin „pozycja syntaktyczna”. Ponadto - jak sam pisze - dokonuje modyfikacji składniowej interpretacji niewymaganych członów zdaniowych. Wprowadzone przez niego zmiany są jednak dużo większe, niż sam sugeruje. Modyfikuje on bowiem nie tyle frazy niewymagane, ile w ogóle pojęcie frazy, i to nie tyle modyfikuje, co zmienia. W SWJP definicja frazy oparta jest na pojęciu funkcji pełnionej w konstrukcji wyższego rzędu. Od rodzaju tej funkcji (typu wymagania konotacyjnego lub braku tego wymagania) zależy typ frazy zdaniowej. U Wiśniewskiego fraza to „zbiór grup syntaktycznych wchodzących $\mathrm{w}$ jednakowe relacje akomodacyjne $\mathrm{z}$ nadrzędnikiem (...)”. Jest to różnica zasadnicza, jak widać bowiem autorzy SWJP opierają się na konotacji, a M. Wiśniewski na akomodacji. Choć nie zgadzam się z takim ujęciem analizowanej tu jednostki, muszę przyznać, że metoda autora Dystrybucyjnych właściwości odprzymiotnikowych nazw cech we wspótczesnej polszczyźnie zyskuje na konsekwencji. Pojęcie „grupy syntaktycznej” pozostało niezmienione, rozumiane jako ciąg form 
wyrazowych „definiowanych morfologicznie, przede wszystkim ze względu na klasę gramatyczną reprezentanta, budowę wewnętrzną" (s. 70), a wprowadzone do opisu pojęcie „pozycji” zostało przejęte z prac M. Szupryczyńskiej i zdefiniowane jako „miejsce składnika zależnego, czyli członu podrzędnego konstrukcji składniowej niewspółrzędnej” (za M. Wiśniewski, s. 70).

W swojej analizie M. Wiśniewski wychodzi od ustalenia pozycji składniowych danego $N E(A d j)$, znajduje wszystkie możliwe realizacje tych pozycji przez różne grupy składniowe, mogące być wykładnikami różnego typu fraz, które z kolei charakteryzuje i klasyfikuje na podstawie analizy akomodacyjnej (por. s. 70). Występująca na przykład w poniższych zdaniach forma uległości otwiera pozycję, w której mogą się pojawić alternatywnie dwa typy fraz: nominalna w celowniku lub przyimkowa o wartości WOBEC, wyróżnione oczywiście na podstawie wymagań akomodacyjnych. Realizacją każdej z tych fraz mogą być różne rodzaje grup; w przytoczonych zdaniach są to kolejno grupy: rzeczownikowa i przymiotnikowa oraz przyimkowo-rzeczownikowa i przyimkowo-przymiotnikowa (sklasyfikowane na podstawie budowy wewnętrznej), por.:

\section{Zmuszat żonę do ulegtości jego rodzicom (każdemu spośród jego krewnych).}

Zmuszat żonę do ulegtości wobec jego rodziców (wobec każdego spośród jego krewnych).

Pozycje składniowe są wyznaczane na podstawie testu niekookurencji i testu koordynacji.

W swojej terminologii M. Wiśniewski - na co warto zwrócić uwagę - rozróżnia pojęcie ekwiwalencji pozycyjnej i ekwiwalencji dystrybucyjnej: ta pierwsza zachodzi na poziomie pozycji, ta druga - na poziomie fraz. Decyzja ta wskazuje na dbałość autora o spójność tworzonej przez niego metodologii. Jest logiczną konsekwencją wprowadzenia trzeciego poziomu jednostek syntaktycznych - pozycji - do przyjętego ujęcia opisu.

M. Wiśniewski wprowadza również zmiany do proponowanego przez autorów SWJP opisu akomodacyjnego. Przyjmując za nimi definicję akomodacji syntaktycznej i rozróżnienie trzech typów związków akomodacyjnych: morfologicznej, słownikowej i czysto składniowej, jednocześnie zapowiada skomentowanie i uściślenie sposobu odróżniania związków akomodacyjnych i nieakomodacyjnych. Proponowanym przez Z. Saloniego i M. Swidzińskiego testem jest substytucja: za nieakomodowane uznają oni człony „dość swobodnie wymienne $\mathrm{z}$ innymi formami wyrazowymi" (za Wiśniewski, s. 75). Autor recenzowanej pracy, uznając sformułowanie „dość swobodnie” za niewystarczające, wprowadza nowe ustalenia. W procedurze postępowania analitycznego dzieli człony składniowe na swobodnie wymienne $\mathrm{z}$ innymi członami, w tym - co istotne - koniecznie $\mathrm{z}$ grupami partykuło-przysłówkowymi, np. popularność w kraju - na obozie - tu $\boldsymbol{i}$ ówdzie. Te uznaje za nieakomodowane bez żadnych wątpliwości. Pozostałe są „podejrzane” o to, że tworzą związki akomodacyjne. Ale żeby zostać za takie 
uznane, muszą spełnić kilka warunków, innych dla grup endocentrycznych, a innych dla egzocentrycznych. Człon endocentryczny jest akomodowany wówczas, jeśli nie można go wymienić na żaden inny o zmienionych parametrach fleksyjnych; kategoria fleksyjna, której nie można zmienić, jest akomodowana. Grupy egzocentryczne natomiast są uznawane za akomodowane, jeśli nie mogą zostać wymienione na inną lub jeśli można je wymienić na nie więcej niż jedną inną grupę - mamy wówczas do czynienia $\mathrm{z}$ akomodacją alternatywną. Co istotne, zamiany grup można dokonywać tylko w obrębie członów równoważnych dystrybucyjnie. Proponowane przez M. Wiśniewskiego warunki akomodacyjności jednostek składniowych są bardzo precyzyjne i konsekwentne. Niewątpliwie ułatwiają analizę akomodacyjną. Łatwo na przykład wyjaśnić, dlaczego leksemowi WIERZYĆ przypisujemy kolejno akomodację przypadka, przyimkowości i typu frazy zdaniowej w grupach wierzę matce, wierze $w$ matkę i wierzę, że matka mi pomoże. Jego podrzędniki są bowiem niewymienialne w obrębie swoich równoważników dystrybucyjnych. Takie ujęcie akomodacji ma jednak również istotne, moim zdaniem, mankamenty, o czym niżej.

Wydaje się, że proponowany w niniejszej pracy opis akomodacyjny dużo dalej odchodzi od istoty akomodacji w ujęciu autorów SWJP, niż wprost przyznaje to Wiśniewski. Po pierwsze, wprowadzone procedury niejako kierują naszą uwagę na skutek, a nie na przyczynę. Istotne w akomodacji jest to, że człon akomodujący narzuca członowi akomodowanemu określoną formę, albo inaczej - że dokonuje wyboru ściśle określonej formy, przy czym dopuszczona jest możliwość, że tych ściśle określonych form będzie więcej niż jedna. Najczęściej jest jedna czy dwie, bo na tym polega ta określoność, ale jeśli zdarzy się większa liczba wymiennych form - to przy zachowaniu warunku akomodacyjności - nie przekreśla jej. Na przykład, czasownikowi CHCIEĆ przypiszemy akomodację biernika, choć jego formy mogą się łączyć również z dopełniaczem, por. chcę mleko - chcę mleka; czasownikowi MYŚLEĆ przypiszemy akomodację typu frazy zdaniowej, chociaż przy jego formach mogą pojawić się więcej niż dwa jej typy, por. myślę o tym, że jest zimno - myślę o tym, żeby było ciepło - myślę o tym, czy będzie ciepło, analogicznie jak dla pamiętam o tym, że trzeba się ciepło ubrać, pamiętam o tym, żeby ciepto się ubrać. Ograniczenie liczby wymiennych grup do dwóch wydaje się zbyt mechaniczne.

Po drugie, inny zakres nadaje M. Wiśniewski pojęciu akomodacji alternatywnej. Za taką uzna mianowicie na przykład zilustrowane wyżej wymagania leksemu czasownikowego PAMIĘTAĆ. Ale przecież leksem ten łączy się również z grupą przyimkową O + Loc, np. pamiętam o mrozach. Jak to wymaganie włączyć do opisu akomodacyjnego leksemu PAMIĘTAĆ? Podobnie, jak zinterpretować cechy akomodacyjne na przykład czasownika LUBIĆ, który akomoduje za- 
równo biernik (lubię zimę), jak bezokolicznik (lubię wygrzewać się przy komin$k u$ ) i frazę zdaniową (lubię, kiedy jest ciepło).

Powyższe uwagi dotyczą analizy akomodacyjnej w ogóle. W wybranym przez autora materiale tego typu problemy nie występują, toteż zaproponowany przez niego bardzo precyzyjna metoda opisu akomodacyjnego daje równie prezycyjny opis.

Przygotowane przez M. Wiśniewskiego narzędzia analizy konotacyjnej i akomodacyjnej, a także elementy analizy transformacyjnej posłużyły mu do strukturalnej charakterystyki podrzędników $N E(A d j)$, na podstawie których opracował kryteria gramatyczne klasyfikacji tychże. Biorąc je pod uwagę, wyróżnił 13 grup podrzędników i na tej podstawie przypisał do określonego typu frazy. Dystrybucyjna klasyfikacja odprzymiotnikowych nazw cech oparta została właśnie na cechach dystrybucyjnych towarzyszących im podrzędników, charakteryzowanych jako określona struktura pozycji przez te podrzędniki zajmowanych. Dokładniej brane były pod uwagę dwa czynniki: liczba zajmowanych przez podrzędniki pozycji przy $N E(A d j)$ i możliwości realizacji poszczególnych pozycji składniowych podrzędników. Kryteria te doprowadziły do wyróżnienia 28 grup $N E$ (Adj). $15 \mathrm{z}$ nich to zbiory jednorodne, tzn. takie, które miały taką samą liczbę otwieranych pozycji realizowanych przez wykładniki tych samych fraz. Pozostałe to jednostki niejednorodne pod względem dystrybucyjnym, ponieważ, co prawda, otwierają taką samą liczbę pozycji, ale wszystkie czy niektóre z nich mogą być realizowane przez alternujące ze sobą wykładniki różnych fraz. Te grupy zostały podzielone na klasy, tj. zbiory $N E(A d j)$, które otwierają dla swoich podrzędników taką samą liczbą tak samo realizowanych pozycji syntaktycznych.

Cały rozdział III poświęcony jest szczegółowej, a nawet można rzec - drobiazgowej, charakterystyce dystrybucyjnej wszystkich grup oraz klas. Autor konsekwentnie stosuje w niej przedstawione w rozdziale II narzędzia analizy składniowej, dzięki czemu udało mu się stworzyć spójny metodologicznie, dokładny opis dystrybucyjnych właściwości odprzymiotnikowych nazw cech, a jednocześnie wskazać, które z nich i w jakim zakresie odziedziczyły wymagania składniowe po bazowych przymiotnikach. Ta informacja z pewnością okaże się bardzo przydatna dla leksykografów. 